\title{
Bioabsorbable osteofixation for orthognathic surgery
}

Young-Wook Park

\begin{abstract}
Orthognathic surgery requires stable fixation for uneventful healing of osteotomized bony segments and optimal remodeling. Titanium plates and screws have been accepted as the gold standard for rigid fixation in orthognathic surgery. Although titanium osteofixation is the most widely used approach, the use of bioabsorbable devices has been increasing recently. Biodegradation of bioabsorbable devices eliminates the need for a second operation to remove metal plates and screws. However, long-term stability and relapse frequency in bioabsorbable osteofixation are still insufficiently studied, especially in cases of segmental movements of great magnitude or segmental movements to a position where bony resistance exists. This paper reviews the background, techniques, and complications of bioabsorbable osteofixation and compares bioabsorbable and titanium osteofixation in orthognathic surgery in terms of skeletal stability.
\end{abstract}

Keywords: Orthognathic surgery; Bioabsorbable plate; Biodegradation; Skeletal stability

\section{Introduction}

Successful orthognathic surgery requires a comprehensive surgical plan, effective osteofixation system for long-term skeletal stability, and achieving satisfactory esthetic facial appearance. Recently, bimaxillary orthognathic surgery has become popular because mandibular setback does not completely remove the midfacial symptoms of mandibular prognathism, which is often found in oriental races. Consequently, oral and maxillofacial surgeons need to perform more complicated surgery, which requires major segmental movements, i.e., those of greater magnitude or movements to a position where bony resistance exists.

Recent trends in orthognathic surgery include control of the occlusal plane to reduce the length of the face and application of so called "functional orthognathic surgery", which means surgery first, orthodontic treatment later for patient's convenience. These trends result in major bone movements with unstable occlusal interdigitation. Therefore, the need for rigid fixation becomes more important in modern orthognathic surgery. For a long time, titanium plates and screws have been considered to

Correspondence: ywpark@gwnu.ac.kr

Department of Oral and Maxillofacial Surgery, College of Dentistry,

Gangneung-Wonju National University, 7 Jukheon-gil, Gangneung 210-702, Korea

\section{Conformation}

\section{Conformation}

The idea of biodegradable plates may have emerged from absorbable sutures. In 1966, polylactic acid, which

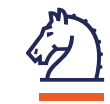
creativecommons.org/publicdomain/zero/1.0/) applies to the data made available in this article, unless otherwise stated. surgery. Although titanium binds to the bone and asymptomatic bone plates can be retained [1], titanium plates should be removed due to growth disturbance, possible to cold exposure, interference with radiopatients' requests $[2-5]$.

Oral and maxillofacial surgeons are increasingly using bioabsorbable devices because they eliminate the need for lesome second operations to remove metal devices. and screws in orthognathic surgery regarding postoperative stability and relapse frequency [6-10]. However, there are few reports concerning postoperative skeletal stability after bioabsorbable osteofixation in a series of orthognathic cases accompanying major maxillomandibular segmental movements [10]. This review highlights the evolution of resorbable osteosynthesis technology and postoperative stability of bioabsorbable osteosynthesis in orthognathic surgery. 
Table 1 Commercially available resorbable or bioabsorbable devices for osteofixation

\begin{tabular}{|c|c|c|c|c|}
\hline Product & Manufacturer & Year of invention & Conformation & Biodegradation period \\
\hline$\overline{\text { Biofix }^{\oplus}}$ & BionX & 1984 & SR-PGA & 6 weeks \\
\hline Orthosorb ${ }^{\circledast}$ & Depuy & 1991 & PDS & 6 months \\
\hline FixsorbMX ${ }^{\circledR}$ & Takiron & 1994 & PLLA & 2 years \\
\hline Lactosorb ${ }^{\otimes}$ & Walter Lorenz & 1996 & PLLA/PGA & 12-18 months \\
\hline MacroSorb ${ }^{\oplus}$ & Macropore & 1999 & P-L/D-LA & 2 years \\
\hline ResorbX ${ }^{\circledast}$ & KLS martin & 2001 & P-L/D-LA & 2 years \\
\hline Inion CPS ${ }^{\oplus}$ & Inion & 2001 & P-L/D-LA & 2 years \\
\hline BiosorbFX ${ }^{\circledR}$ & Bionix Implants & 2001 & P-L/D-LA & 2 years \\
\hline PolyMax ${ }^{\oplus}$ & Synthes & 2003 & P-L/D-LA & 2 years \\
\hline Delta System ${ }^{\circledast}$ & Stryker & 2004 & P-L/D-LA /GA & 2 years \\
\hline OsteotransMX ${ }^{\circledR}$ & Takiron & 2007 & u-HA/PLLA & 5.5 years \\
\hline Inion CPS ${ }^{\circledast}$ & Inion & 2007 & P-L/D-LA/TMC & 2 years \\
\hline
\end{tabular}

SR-PGA: Self-reinforced polyglycolic acid.

PDS: Polydioxanone.

PLLA: Poly-L-lactic acid.

PDLA: Poly-D-lactic acid.

u-HA: unsintered hydroxyapatite.

TMC: trimethylenecarbonate.

is a major component of biodegradable polymers, was first proposed for surgical implants [11]. The use of biodegradable materials to stabilize the fractured facial skeleton was first reported in 1971[12]. Since then, resorbable polymeric plates and screws have been used widely in pediatric patients with maxillofacial traumas because permanent fixation might hinder their facial growth [13]. At first, the strength of resorbable plates and screws was poor, but the strength of the devices was increased by using self-reinforcement technology. Finally, encouraging results were reported in the treatment of mandibular fractures $[14,15]$ and orthognathic surgery[16,17]. Recently, the concept has been changed from simply "resorbable" to "bioabsorbable", which means biodegradation plus stimulation of osteoconduction. Commercially available resorbable and bioabsorbable devices are listed in Table 1.

The ideal biodegradable material should not only support bone fragments during healing, but also resorb fully once the healing process is completed, and the resulting metabolites should not cause any local or systemic problems. In addition, the required amounts of such material must be small and it must be flexible to be applied at variable maxillofacial bone sites. Three resorbable materials, polyglycolic acid (PGA), poly-L-lactic acid (PLLA), and poly-D-lactic acid (PDLA), have been introduced (Figure 1). Self-reinforced PGA devices are rapidly degradable, semirigid and disappear by 6 weeks after implantation; they are used in neurosurgery due to their low strength [18]. The total resorption time of PLLA is over 3.5 years [19]. A PLLA device, FixsorbMX ${ }^{\odot}$ (Takiron, Osaka, Japan), has been used in facial bone surgery. The reported problems were insufficient intensity of materials, foreign-body reactions and late degradation tissue response [20].

Polymers and copolymers of PGA, PLLA, and PDLA were given preference over pure PGA and PLLA [21]. Lactosorb $^{\oplus}$ (Walter Lorenz Surgical Inc., Jacksonville, Florida, USA) is a copolymer of PLLA (82\%) and PGA (18\%). The copolymer is structured to provide adequate strength for 6-8 weeks and to allow a resorption time of 12-18 months [22]. It is metabolized via the citric acid

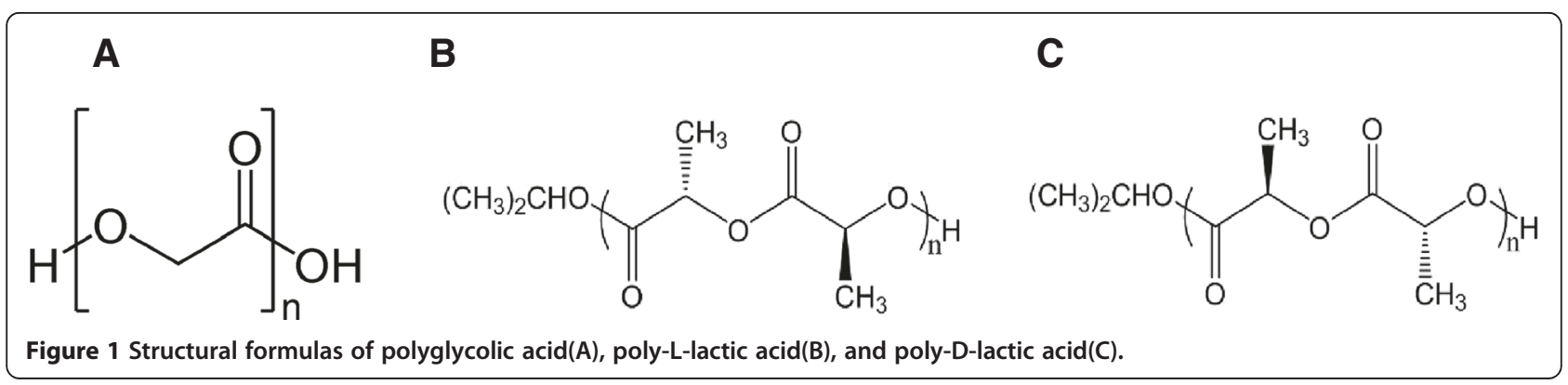




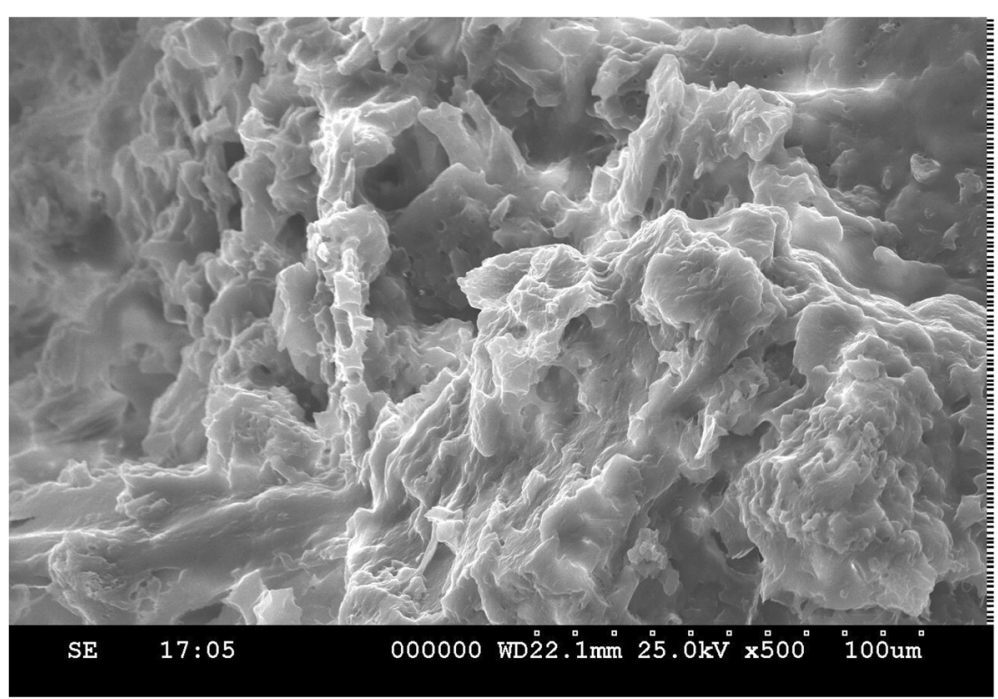

Figure 2 SEM image showing degrading amorphous 70:30 poly-L/D-lactide copolymer plate, which was explanted 1 year after implantation for osteofixation of mandibular SSRO site.

cycle and is eventually excreted by the lungs as carbon dioxide and water [23].

BiosorbFX ${ }^{\bullet}$ (Bionix Implants Inc., Tampere, Finland) is a copolymer of D-lactide (30\%) and L-lactide (70\%). Clinical papers have reported stable results in orthognathic surgery due to its adequate strength [24,25]. Amorphous 70:30 poly-L/D-lactide copolymer plates are hydrolyzed through water penetration into the plate, which breaks the copolymer chains into smaller particles (Figure 2). In contrast to macrocrystalline PLLA structures, hydrolyzed amorphous copolymer can be readily degraded by phagocytic cells to carbon dioxide and water [26].
Recently, hydroxyapatite has been incorporated into PLLA because of the documented osteoconductive capacity of the former. OsteotransMX ${ }^{\bullet}$ (Takiron) plates are made of a composite material consisting of fine particles of unsintered hydroxyapatite (u-HA) and carbonate ion combined with PLLA. As they are osteoconductive and biodegradable, the u-HA/PLLA nano-composites demonstrate the potential for complete replacement by bony tissue [27]. Furthermore, these devices maintain a bending strength equal to that of human cortical bone for 25 weeks in vivo [28]. Once it has been implanted, PLLA starts to be hydrolyzed by body fluids and to undergo

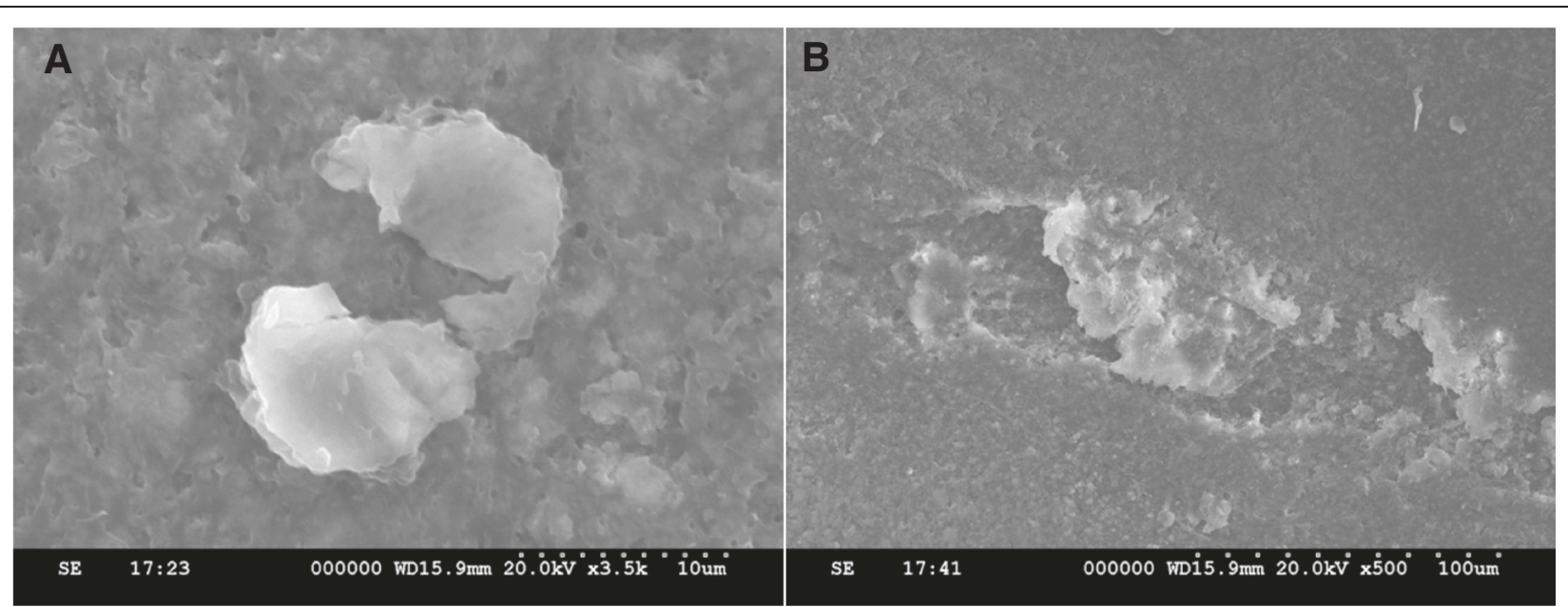

Figure 3 SEM image showing that a macrophage is attached the surface of u-HA/PLLA nano-composite plate, which explanted 7 months after operation (A). (B) A defect on the surface of the bioabsorbable plate by macrophage indicates that a process of biodegradation is in progress. 
biodegradation (Figure 3). The molecular weight of PLLA decreases and the u-HA fraction increases for about 2 years. The PLLA matrix is completely absent from the composites after 4 years, and almost all u-HA particles are replaced with bone after 5.5 years [29]. In comparison with early resorbable polymers, u-HA/PLLA osteoconductive composites provide more stable segment retention in orthognathic surgery [30].

Ballon et al. [31] have conducted a clinical study using a new polymer composition for resorbable osteosynthesis, poly-L/D-lactide-trimethylenecarbonate (TMC) (Inion, Tampere, Finland). P-L/D-lactide-TMC osteosynthesis seemed to have less strength against compressive forces after maxillary elongation and it is less resistant to the forces exerted by the tongue pressing against the mandible after setback [31].

\section{Clinical Applications}

One 2.4-mm, 6-hole poly-L/DL-lactide plate and monocortical screws are applied at the mandibular sagittal split ramus osteotomy (SSRO) site. Three 6-mm screws are engaged into the proximal segments, and two screws are engaged in the distal segment, usually located below the inferior alveolar canal. One hole, located in the osteotomy gap, can be left empty if other screws are sufficiently tight (Figure 4). Other standard methods for osteosynthesis of mandibular SSRO are the triangular placement of bicortical screws [32,33] or the use of two mini-plates and monocortical screws. When two plates are applied, one is located above the inferior alveolar canal, and the other one is below the canal.

Regardless of the fixation method, mandibular setback remains a more unstable movement than mandibular advancement [34-36]. One mini-resorbable plate for fixation of mandibular SSRO with mandibular setback seems to lead to segment mobility in early postoperative period. A $0.7 \mathrm{~mm}$-thick u-HA/PLLA mesh (Osteotrans$\mathrm{MX}^{\circ}$ ) can be also applied after mandibular SSRO, especially when major segmental movements have been performed. Osteosynthesis by using u-HA/PLLA devices in orthognathic surgery is reliable because of their rigidity as well as osteoconductivity and bone-bonding capacity [37]. Mandibular symphyseal osteotomies have also been safely fixed with appropriate bioabsorbable plates and monocortical screws (Figure 5).

The Le Fort I osteotomies are stabilized with four L-shaped resorbable or bioabsorbable plates and secured bilaterally in the pyriform aperture and zygomatic buttress. Reliable results have also been reported with the use of a biodegradable mesh $[38,39]$. Segmental Le Fort I osteotomy is also stabilized with the above standard fixation, i.e., the use of four $1.2 \mathrm{~mm}$-thick, 7-hole L-type poly-L/D-lactide plates [40].

\section{Complications}

The drawbacks of using resorbable devices include their higher cost and some technical problems due to the characteristics of the material itself, postoperative plate fractures, and development of delayed foreign-body reactions. In 2003, Landes et al. reported that $27 \%$ of patients had complications after resorbable plate osteosynthesis of sagittal split osteotomies with major bone movement [41]. The complication rate is now decreasing thanks to the development of new material compositions as well as improvement of surgical skills. Cheung et al. have concluded that the introduction of resorbable devices did not lead to an increase in intraoperative morbidities and postoperative complications [42].

Material-specific complications during operation include screw fractures, the need for wider dissection due to the

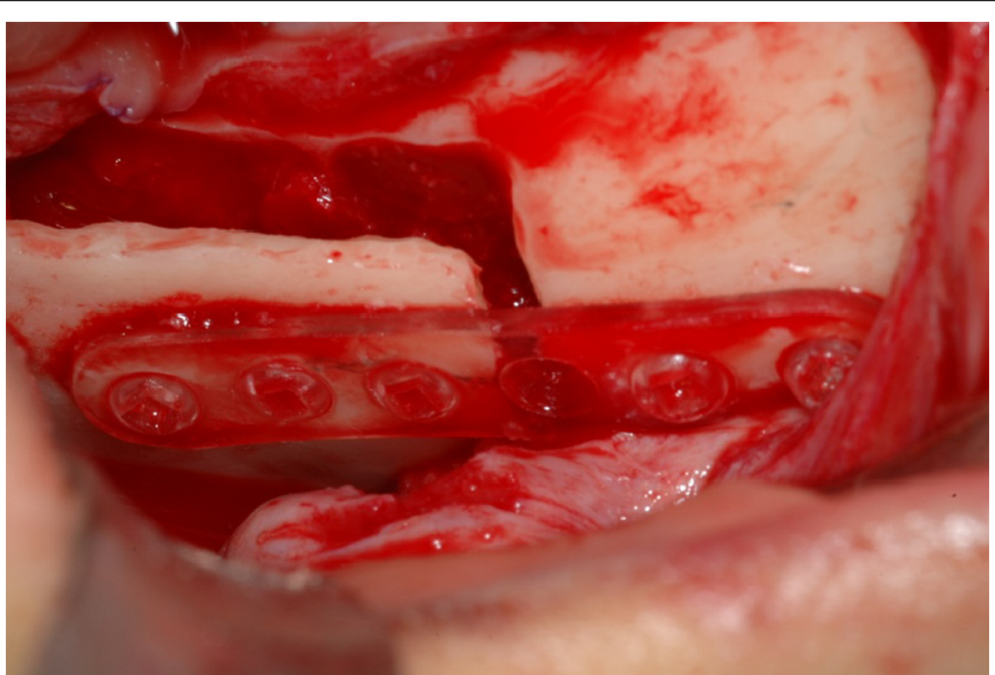

Figure 4 A $2.4 \mathrm{~mm}$ 6-hole poly-L/D-lactide plate is applied for fixation of mandibular SSRO. 


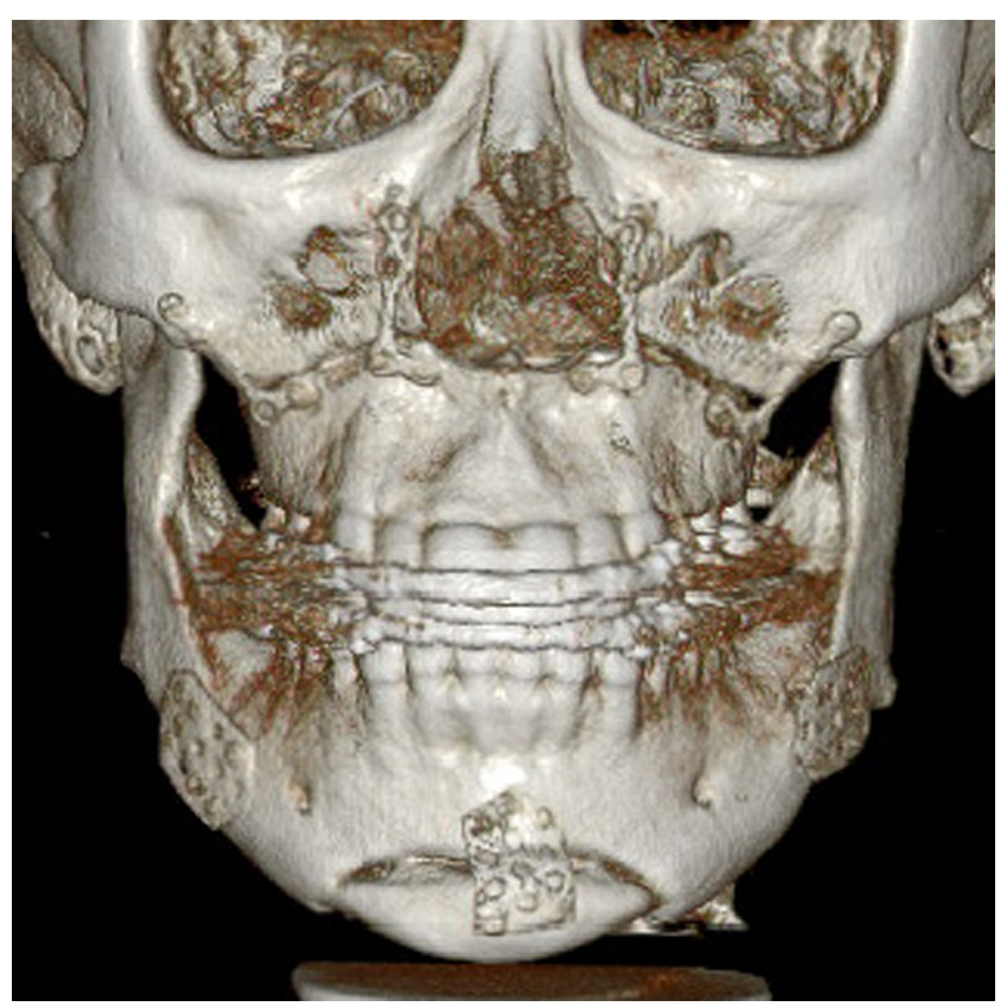

Figure 5 3-dimensional reconstructed CT image showing maxillomandibular osteotomy with simultaneous genioplasty and fixation with u-HA/PLLA composite bioabsorbable devices in a female patient with mandibular prognathism. Maxillary osteosynthesis was performed with four L-type mini-sized plates, and mandibular osteosynthesis was performed using bioabsorbable mesh and monocortical screws.

larger sizes of resorbable devices, and difficulties in molding the devices into the desired shape. Screw fractures occur most often in screw heads when excessive force from the screwdriver is applied. A new hole is drilled through the fractured screw or an emergency screw can be used if adequate fixation cannot be obtained with a regular one. The need to increase the dimension for application during surgery has been recently met by using smaller products. Poly-L/D lactide plates and u-HA/PLLA composite plates are easily bendable with fingers at room temperature, combining wave-forms with angles and torsions, and can be maintained in the desired position without heating so far as slower bending and less force are applied. OsteotransMX ${ }^{\odot}$ plates are bendable to 40 degrees at room temperature [30]. Preshaped bent plates are also commercially available, or a boiling-water bath can be used.

Titanium plates may also be fractured by excessive forces. Fractures of resorbable devices are more problematic when major segmental movements are performed in orthognathic surgery. There are few published clinical studies on the incidence of postoperative plate fractures when resorbable or bioabsorbable plates and screws are used. According to the author's clinical experience, one 2.4- $\mathrm{mm}$ poly-L/D-lactide plate seems to be more stable than two mini-bioabsorbable plates. Only one case of plate fracture was recognized with the use of these plates in a series of 63 bimaxillary orthognathic surgery patients (126 osteofixations) in comparison with 3 cases out of 139 osteofixations when two mini-plates at a SSRO site were used (Figure 6). In a randomized controlled study, the incidence of plate removal was higher in maxillofacial surgery with the biodegradable system in comparison with titanium fixation [43].

Inflammatory complications may also develop, especially in the mandible. Localized soft tissue inflammation may be associated with a fractured absorbable plate. Intraoral pathogens also induce localized inflammatory lesions around the absorbable devices when inadvertently inoculated. In this case, histological examination demonstrates a granulomatous lesion heavily infiltrated with macrophages and small round cells. However, sections of the tissue in the vicinity of the absorbable plate showed fibrous scar tissue into which few inflammatory cells had infiltrated (Figure 7). Some clinical studies have reported that foreign-body inflammatory reactions develop with the use of PLLA $[44,45]$. At a later degradation stage, hydrolyzed, disintegrated PLLA undergoes enzymolysis. Remaining crystal-like PLLA particles may trigger the foreign-body inflammatory reaction, although 


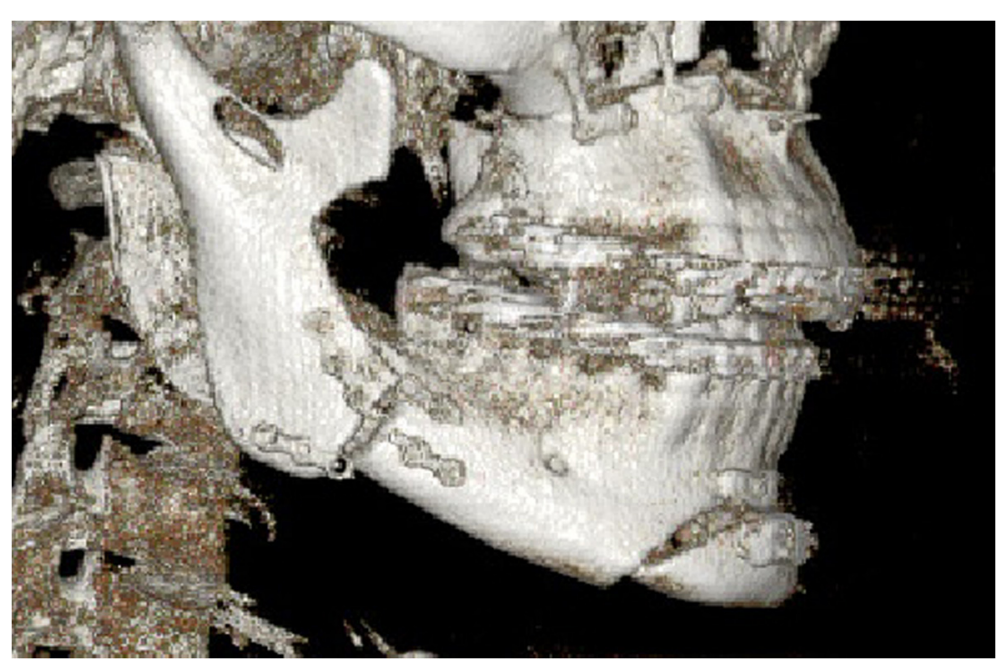

Figure 6 3-dimensional reconstructed CT image showing that two mini-sized, bioabsorbable plates are fractured 7 weeks after implatation.

they are not very irritating to the host cells (Figure 8). In addition, an uneven release of PLLA fragments can cause physical inflammatory reaction, but the incidence is rare [29]. These inflammatory lesions can be successfully treated with routine drainage and antibiotics.

\section{Skeletal Stability}

An increasing number of clinical reports concerned with skeletal stability and relapses after bioabsorbable polymer osteosyntheses in orthognathic surgery are found in PubMed. Haers et al. reported predictable short-term skeletal stability with the use of poly-L/DL-lactide plates and screws in 10 consecutive cases of bimaxillary procedures with simultaneous genioplasties [46]. Shand et al. reported mild mobility of the maxilla in the early postoperative period with the use of Lactosorb ${ }^{\circ}$ bicortical screws for stabilization of mandibular SSRO in bimaxillary orthognathic surgery. However, stability was within normal limits at 6 weeks postoperatively [47].
Mandibular mobility in the early postoperative period was noted, especially when strong elastics were applied immediately postoperatively, but this problem could be easily overcome by gradual application of rubber force and avoidance of occlusal stress. In the author's experience, none of bimaxillary orthognathic surgery patients $(n=153)$ treated after 2002 had fragment displacement that required refixation. All minor occlusal discrepancies were successfully controlled with elastic bands and guided occlusion. No malocclusions were noted during the follow-up period of at least 2 years. However, Ahn et al. reported a higher incidence of complications in patients with resorbable fixation compared with nonresorbable fixation in terms of postoperative anterior open bite and relapse frequency [48].

According to a preliminary report from another group, postoperative osseous movement was small when polyL/DL-polylactide plates were used [49]. As a result, resorbable osteofixation permitted clinically faster occlusal and condylar setting than titanium osteosynthesis,

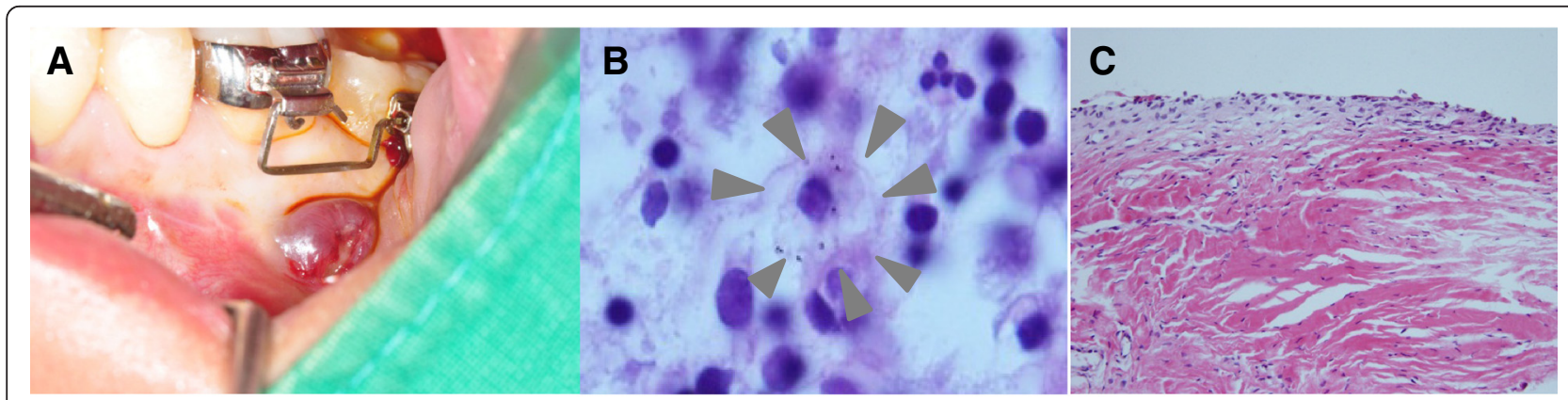

Figure 7 A case of inflammatory complication. (A) A localized inflammatory lesion was developed 8 months after operation. (B) A

macrophage contained microorganisms in their cytoplasm (gray arrowheads, H\&E, X200). (C) Section from the tissue in the vicinity of the u-HA/PLLA plate, showed fibrous scar tissue without inflammatory reaction. In the figure, upper border was in contact with the plate (H\&E, X40). 


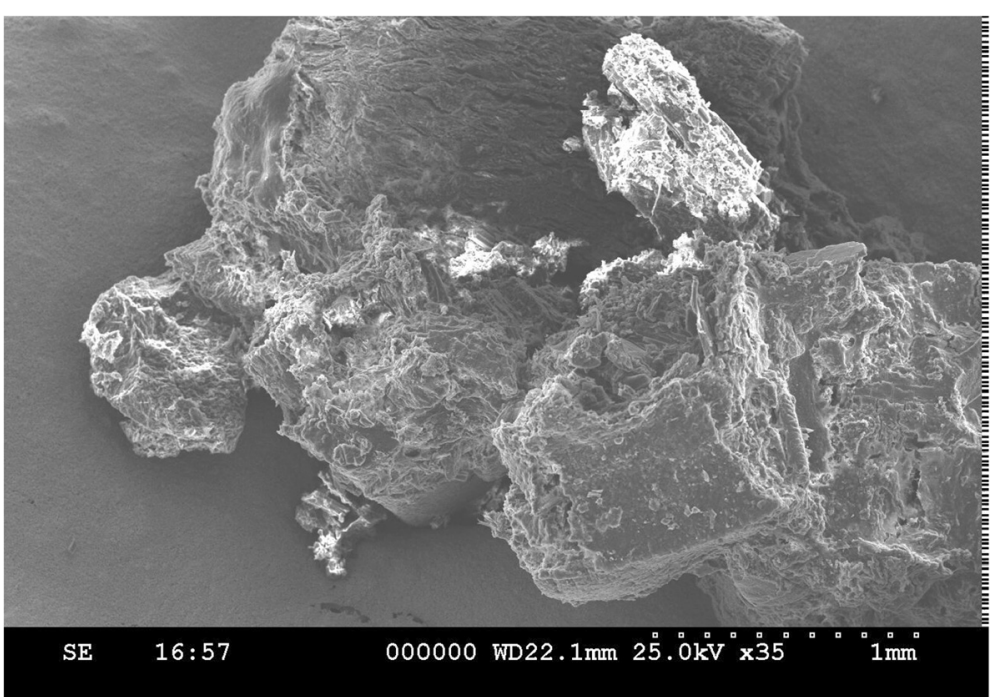

Figure 8 SEM image showing crystal-like PLLA material internalized by various cells.

because segments showed low mobility in cleft lip and palate orthognathic surgery [49]. Other researchers have demonstrated that resorbable devices did not increase segmental mobility or long-term instability compared with titanium plates in orthognathic surgery, including sagittal splitting of mandibular ramus and mandibular advancement [50,51]. In mandibular setback surgery, Paeng et al. suggested that bicortical resorbable screws offered a clinically stable outcome except for vertical measurements, compared with titanium fixation $(n=25)$ [52]. Ueki et al. concluded that the change in condylar angle after SSRO was greater in the group with titanium fixation than in the group with PLLA fixation $(n=20$ per group) [53].

In bimaxillary orthognathic surgery, PLLA/PGA plates appear to provide stable osteosynthesis for maxillary advancement of up to $5 \mathrm{~mm}$ [54]. In another study on the bimaxillary procedure, a slight tendency for vertical relapse was reported in the group with PLLA osteofixation compared to the titanium osteofixation group, but the differences were not clinically significant and finally normal occlusion was established in both groups [30]. Another retrospective study aimed to determine the differences in postoperative stability between poly-L/Dlactide and titanium plate systems used for fixation in bimaxillary orthognathic surgery, in particular maxillary posterior impaction surgery $(n=30)$ [55]. Six months after surgery, there was no significant difference between the groups, as analyzed by lateral cephalogram. Furthermore, when segmental Le Fort I osteotomy for major movement of maxilla $(n=15)$ in bimaxillary orthognathic surgery was performed, the maxillary position remained stable with resorbable osteosyntheis [40].
No significant difference in the postsurgical relapse rate after mandibular setback surgery was found in the resorbable plate group [56]. Absolute postoperative skeletal instability was not significantly different between resorbable and titanium plating systems for osteofixation in bimaxillary orthognathic surgery [57-59]. In contrast, Landes et al. reported compromised segmental stability in maxillary elongation and in mandibular setback with u-HA/PLLA composite osteosynthesis. They applied one 1.4-mm 4-hole plate and 8-mm monocortical screws at a mandibular SSRO site and recommended longer intermaxillary fixation, double osteosynthesis or use of larger plates [30]. However, in most studies the groups were not matched for the magnitude or direction of fragment movement. Prospective studies with larger patient numbers are needed.

\section{Conclusions}

The use of bioabsorbable devices has resolved several problems of titanium fixation, such as the need for a second operation and interference with radiological evaluation. From the literature review, the author concluded that bioabsorbable osteosynthesis systems are reliable for fragment fixation in orthognathic procedures with major maxillomandibular segmental movements. The use of bioabsorbable devices leads to predictable postoperative long-term skeletal stability, which appears to be similar to that provided by titanium devices. In the future, we need less expensive bioabsorbable devices that degrade rapidly in the body.

\section{Competing interests}

The authors declare that he has no competing interests. 
Received: 11 January 2015 Accepted: 11 January 2015

Published online: 19 February 2015

\section{References}

1. Haug RH (1996) Retention of asymptomatic bone plates used for orthognathic surgery and facial fractures. J Oral Maxillofac Surg 54:611-617

2. Lalor PA, Revell PA, Gray AB, Wright S, Railton GT, Freemen MA (1991) Sensitivity to titanium: a cause of implant failure? $\mathrm{Br} J$ Bone Joint Surg 73:25-28

3. France TJ, Birely BC, Ringelman PR, Manson PN (1992) The fate of plates and screws after facial fracture reconstructioin. Plast Reconstr Surg 90:568-573

4. Schmidt BL, Perrott DH, Mahan D, Kearns G (1998) The removal of plates and screws after Le Fort I osteotomy. J Oral Maxillofac Surg 56:184-188

5. Ji B, Wang C, Liu L, Long J, Tian W, Wang H (2010) A biomechanical analysis of titanium miniplates used for treatment of mandibular symphyseal fractures with the finite element method. Oral Surg Oral Med Oral Pathol Oral Radiol Endod 109:e21-e27

6. Edwards RC, Kiely KD, Eppley BL (2001) Fixation of bimaxillary osteotomies with resorbable plates and screws: Experience in 20 consecutive cases. J Oral Maxillofac Surg 59:271-276

7. Matthews NS, Khambay BS, Ayoub AF, Koppel D, Wood G (2003) Preliminary assessment of skeletal stability after sagittal split mandibular advancement using a bioresorbable fixation system. Br J Oral Maxillofac Surg 41:179-184

8. Kwon TK, Kim YD, Shin SH, Kim WK, Kim JR, Chung IK (2005) Stability after surgical correction of mandibular prognathism using bilateral saggital split ramus osteotomy and fixation with poly-L/DL-lactide copolymer screws (Biosorb $\left.{ }^{T M} F X\right)$. J Korean Assoc Maxillofac Plast Reconstr Surg 2:160-163

9. Eppley BL (2007) Bioabsorbable plate and screw fixation in orthognathic surgery. J Craniofac Surg 18:818-825

10. Tuovinen V, Suuronen R, Teittinen M, Nurmenniemi P (2010) Comparison of the stability of bioabsorbable and titanium osteosynthesis materials for rigid internal fixation in orthognathic surgery. A prospective randomized controlled study in 101 patients with 192 osteotomies. Int J Oral Maxillofac Surg 39:1059-1065

11. Kulkarni RK, Pani KC, Neuman C, Leonard F (1966) Polylactic acid for surgical implants. Arch Surg 93:839-843

12. Cutright DE, Hunsuck EE, Beasley JD (1971) Fracture reduction using a biodegradable material, polylactic acid. J Oral Surg 29:393-397

13. Suuronen R, Kallela I, Lindqvist C (2000) Bioabsorbable plates and screws: Current state of the art in facial fracture repair. J Craniomaxillofac Trauma 6:19-27

14. Ylikontiola L, Sundqvuist K, Sàndor GK, Törmälä P, Ashammakhi N (2004) Self-reinforced bioresorbable poly-L/DL-lactide [SR-P(L/DL)LA] 70/30 miniplates and miniscrews are reliable for fixation of anterior mandibular fractures: a pilot study. Oral Surg Oral Med Oral Pathol Oral Radiol Endod 97:312-317

15. Choi J, Kim JR, Ha TJ, Yu JB, Kim IK (2005) The prognosis of fixation of mandibular fractures with biodegradable plates and screws. J Korean Assoc Maxillofac Plast Reconstr Surg 1:32-38

16. Mohamed-Hashem IK, Mitchell DA (2000) Resorbable implants (plates and screws) in orthognathic surgery. J Orthod 27:198-199

17. Turvey TA, Bell RB, Tejera TJ, Proffit WR (2002) The use of self-reinforced biodegradable bone plates and screws in orthognathic surgery. J Oral Maxillofac Surg 60:59-65

18. Peltoniemi HH, Tulamo RM, Toivonen $T$, Hallikainen D, Tormala P, Waris $T$ (1999) Biodegradable semirigid plate and miniscrew fixation compared with rigid titanium fixation in experimental calvarial osteotomy. J Neurosurg 90:910-917

19. Bergsma EJ, de Bruijn WC, Rozema FR, Bos RR, Boering G (1995) Late degradation tissue response to poly (L-lactide) bone plates and screws. Biomaterials 16:25-31

20. Bergsma EJ, Rozema FR, Bos RR, de Bruijn WC (1993) Foreign body reaction to resorbable poly (L-lactide) bone plates and screws used for the fixation of unstable zygomatic fractures. J Oral Maxillofac Surg 51:666-670

21. Surronen R, Haers PE, Lindqvist C, Sailer HF (1999) Update on bioresorbable plates in maxillofacial surgery. Facial Plast Surg 15:61-72

22. Wiltfang J, Merten HA, Schultze-Mosgau S, Schrell U, Wenzel D, Kessler P (2000) Biodegradable miniplates (LactoSorb): long-term results in infant minipigs and clinical results. J Craniofac Surg 11:239-243
23. Edwards RC, Kiely KD, Eppley BL (2001) The fate of resorbable poly-L-lactic/ polyglycolic acid (LactoSorb) bone fixation devices in orthognathic surgery. J Oral Maxillofac Surg 59:19-25

24. Mazzonetto R, Paza AO, Spagnoli DB (2004) A retrospective evaluation of rigid fixation in orthognathic surgery using a biodegradable self-reinforced (70 L:30DL) polylactide. Int J Oral Maxillofac Surg 33:664-669

25. Kim BC, Padwa BL, Park HS, Jung YS (2011) Stability of maxillary position after Le Fort I osteotomy using self-reinforced biodegradable poly-70 L/ 30DL-lactide miniplates and screws. J Oral Maxillofac Surg 69:1442-1446

26. Hochuli-Vieira E, Cabrini Gabrielli MA, Pereira-Filho VA, Gabrielli MF, Padilha JG (2005) Rigid internal fixation with titanium versus bioresorbable miniplates in the repair of mandibular fractures in rabbits. Int J Oral Maxillofac Surg 34:167-173

27. Shikinami Y, Okuno M (1999) Bioresorbable devices made of forged composites of hydroxyapatite (HA) particles and poly L-lactide (PLLA): part I. Basic characteristics. Biomaterials 20:859-877

28. Shikinami Y, Okuno M (2001) Bioresorbable devices made of forged composites of hydroxyapatite (HA) particles and poly L-lactide (PLLA): part II. Practical properties of miniscrews and miniplates. Biomaterials 22:3179-3211

29. Shikinami Y, Matsuse Y, Nakamura T (2005) The complete process of bioresorption and bone replacement using devices made of forged composites of raw hydroxyapatite particles/poly L-lactide (F-U-HA/PLLA). Biomaterials 26:5542-5551

30. Landes CA, Ballon A, Tran A, Ghanaati S, Sader R (2014) Segmental stability in orthognathic surgery: Hydroxyapatite/poly L-lactide osteoconductive composite versus titanium miniplate osteosynthesis. J Craniomaxillofac Surg 41:930-942

31. Ballon A, Laudemann K, Sader R, Landes CA (2012) Segmental stability of resorbable $P(L / D L) L A-T M C$ osteosynthesis versus titanium miniplates in orthognatic surgery. J Craniomaxillofac Surg 40:e408-e414

32. Maurer P, Holweg S, Knoll WD, Schubert J (2002) Study by finite element method of the mechanical stress of selected biodegradable osteosynthesis screws in sagittal ramus osteotomy. Br J Oral Maxillofac Surg 40:76-83.

33. Kallela I, Laine P, Suuronen R, Lindqvist C, lizuka T (2005) Assessment of material- and technique-related complications following sagittal split osteotomies stabilized by biodegradable polylactide screws. Oral Surg Oral Med Oral Pathol Oral Radiol Endod 99:4-10

34. Ueki K, Marukawa K, Shimada M, Nakagawa K, Alam S, Yamamoto E (2006) Maxillary stability following Le Fort I osteotomy in combination with sagittal split ramus osteotomy and intraoral vertical ramus osteotomy: a comparative study between titanium miniplate and poly-L-lactic acid plate. J Oral Maxillofac Surg 64:74-80

35. Kim YK, Kim YJ, Yun PY, Kim JW (2009) Evaluation of skeletal and surgical factors related to relapse of mandibular setback surgery using the bioabsorbable plate. J Craniomaxillofac Surg 37:63-68

36. Ko EW, Huang CS, Lo LJ, Chen YR (2013) Alteration of masticatory electromyographic activity and stability of orthognathic surgery in patients with skeletal class III malocclusion. J Oral Maxillofac Surg 71:1249-1260

37. Ueki K, Okabe K, Miyazaki M, Munozawa A, Mori A, Marukawa K, Nakagawa K, Yamamoto E (2011) Skeletal stability after mandibular setback surgery: comparisons among unsintered hydroxyapatite/poly-L-lactic acid plate, poly-L-lactic acid plate, and titanium plate. J Oral Maxillofac Surg 69:1464-1468

38. Sittitavornwong S, Waite PD, Dann JJ, Kohn MW (2006) The stability of maxillary osteotomies fixated with biodegradable mesh in orthognathic surgery. J Oral Maxillofac Surg 64:1631-1634

39. Meara DJ, Knoll MR, Holmes JD, Clark DM (2012) Fixation of Le Fort I osteotomies with poly-DL-lactic acid mesh and ultrasonic welding-a new technique. J Oral Maxillofac Surg 70:1139-1144

40. Kim MK, Park YW (2009) Post-operative skeletal stability of the maxilla treated with Le Fort I and U-shaped osteotomies in simultaneous maxillomandibular orthognathic surgery. J Korean Assoc Maxillofac Plast Reconstr Surg 31:485-491

41. Landes CA, Kriener S (2003) Resorbable plate osteosynthesis of sagittal split osteotomies with major bone movement. Plast Reconstr Surg 111:1828-1840

42. Cheung LK, Chow LK, Chiu WK (2004) A randomized controlled trial of resorbable versus titanium fixation for orthognathic surgery. Oral Surg Oral Med Oral Pathol Oral Radiol Endod 98:386-397

43. van Bakelen NB, Buijs GJ, Jansma J, de Visscher JG, Hoppenreijs TJ, Bergsma JE, Stegenga B, Bos RR (2013) Comparison of biodegradable and titanium fixation in maxillofacial surgery: a two-year multi-center randomized controlled trial. J Dent Res 92:1100-1105 
44. Laine P, Kontio R, Lindqvist C, Suuronen R (2004) Are there any complications with bioabsorbable fixation devices? A 10 year review in orthognathic surgery. Int J Oral Maxillofac Surg 33:240-244

45. Turvey TA, Proffit WP, Phillips C (2011) Biodegradable fixation for craniomaxillofacial surgery: a 10-year experience involving 761 operations and 745 patients. Int J Oral Maxillofac Surg 40:244-249

46. Haers PE, Sailer HF (1998) Biodegradable self-reinforced poly-L/DL-lactide plates and screws in bimaxillary orthognathic surgery: short term skeletal stability and material related failures. J Craniomaxillofac Surg 26:363-372

47. Shand JM, Heggie AA (2000) Use of a resorbable fixation system in orthognathic surgery. Br J Oral Maxillofac Surg 38:335-337

48. Ahn YS, Kim SG, Baik SM, Kim BO, Kim HK, Moon SY, Lim SH, Kim YK, Yun PY, Son JS (2010) Comparative study between resorbable and nonresorbable plates in orthognathic surgery. J Oral Maxillofac Surg 68:287-292

49. Landes CA, Ballon A (2006) Five-year experience comparing resorbable to titanium miniplate osteosynthesis in cleft lip and palate orthognathic surgery. Cleft Palate Craniofac J 43:67-74

50. Turvey TA, Bell RB, Phillips C, Proffit WR (2006) Self-reinforced biodegradable screw fixation compared with titanium screw fixation in mandibular advancement. J Oral Maxillofac Surg 64:40-46

51. Stockmann P, Bohm H, Driemel O, Muhling J, Pistner H (2010) Resorbable versus titanium osteosynthesis devices in bilateral sagittal split ramus osteotomy of the mandible - the results of a two centre randomized clinical study with an eight-year follow-up. J Craniomaxillafac Surg 38:522-528

52. Paeng JY, Hong J, Kim CS, Kim MJ (2012) Comparative study of skeletal stability between bicortical resorbable and titanium screw fixation after sagittal split ramus osteotomy for mandibular prognathism.

J Craniomaxillafac Surg 40:660-664

53. Ueki K, Nakagawa K, Marukawa K, Takazakura D, Shimada M, Takatsuka S, Yamamoto E (2005) Changes in condylar long axis and skeletal stability after bilateral sagittal split ramus osteotomy with poly-L-lactic acid or titanium plate fixation. Int J Oral Maxillofac Surg 34:627-634

54. Costa F, Robiony M, Zorzan E, Zerman N, Politi M (2006) Stability of skeletal Class III malocclusion after combined maxillary and mandibular procedures: titanium versus resorbable plates and screws for maxillary fixation. J Oral Maxillofac Surg 64:642-651

55. Park JM, Park YW (2010) Postoperative stability of fixation with absorbables in simultaneous maxillomandibular orthognathic surgery. J Korean Assoc Maxillofac Plast Reconstr Surg 32:126-131

56. Lee JY, Kim YK, Yun PY, Lee NK, Kim JW, Choi JH (2014) Evaluation of stability after orthognathic surgery with minimal orthodontic preparation: comparison according to 3 types of fixation. J Craniofac Surg 25:911-915

57. Landes CA, Ballon A (2006) Skeletal stability in bimaxillary orthognathic surgery: $P(L / D L) L A$-resorbable versus titanium osteofixation. Plast Reconstr Surg 118:703-721

58. Landes CA, Ballon A, Sader R (2007) Segment stability in bimaxillary orthognathic surgery after resorbable Poly(L-lactide-co-glycolide) versus titanium osteosyntheses. J Craniofac Surg 18:1216-1229

59. Moure C, Qassemyar Q, Dunaud O, Neiva C, Testelin S, Devauchelle B (2012) Skeletal stability and morbidity with self-reinforced $P(L / D L) L A$ resorbable osteosynthesis in bimaxillary orthognathic surgery. J Craniomaxillofac Surg 40:55-60

\section{Submit your manuscript to a SpringerOpen ${ }^{\circ}$ journal and benefit from:}

- Convenient online submission

- Rigorous peer review

- Immediate publication on acceptance

- Open access: articles freely available online

- High visibility within the field

- Retaining the copyright to your article

Submit your next manuscript at $>$ springeropen.com 